\title{
STRATEGI DAKWAH PERSATUAN ISLAM (PERSIS) RIAU
}

\author{
Aris Risdiana \\ Program Studi Manajemen Dakwah, Fakultas Dakwah dan Komunikasi \\ UIN Sunan Kalijaga Yogyakarta ${ }^{1}$ \\ Email: arisrisdiana.kalijaga@gmail.com
}

\begin{abstract}
Abstrak
Persatuan Islam (Persis) adalah ormas Islam yang tersebar di banyak wilayah Indonesia, dengan visi turut berkontribusi dalam menyiarkan Islam dan mencetak generasi muslim ideal. Persatuan Islam di provinsi Riau merupakan bagian dari organisasi dakwah ini. Di bawah kepemimpinan Ustadz Yana Mulyana sebagai Ketua Pimpinan Wilayah Persatuan Islam Riau, strategi dakwah Persis disambut hangat oleh masyarakat. Aktifitas dakwah Persis Riau mengusung prinsip ukhuwah (persaudaraan), sehingga tidak mengherankan bila 63 ormas keagamaan yang berbeda bersedia bergabung di bawah komando ustad Yana Mulyana. Penelitian ini, melalui wawancara mendalam dan partisipatoris, menguji bagaimana Persatuan Islam Riau mengkonstruksi strategi dakwah serta melihat respon masyarakat Riau terhadap strategi dakwahnya. Teori Habitus, Arena dan Capital dari Pierre Bourdieu digunakan sebagai pisau bedah untuk menganalisa strategi dakwah Persis Riau dalam memahami historisitas dinamika lokal dan praktik politik keislaman di Riau. Bagaimana Persatuan Islam Riau membuat perencanaan dan strategi dalam rangka menyuarakan idealisme dan kebutuhan massanya berdasarkan kultur masyarakat setempat menjadi topik utama dalam artikel ini.
\end{abstract}

Kata Kunci: Persatuan Islam, Strategi Dakwah, Respon Masyarakat Riau.

${ }^{1}$ Penelitian ini dilaksanakan melalui skema dana hibah dari Lembaga Penelitian dan Pengabdian Masyarakat (LP2M) UIN Sunan Kalijaga Yogyakarta tahun anggaran 2018 untuk Cluster Riset Nasional Wilayah I. 


\section{Pendahuluan}

Persatuan Islam didirikan oleh Haji Zamzam dan Haji Muhammad Yunus pada tahun 1923, menjadi organisasi yang berangkat dari kelompok diskusi. ${ }^{2}$ Diawali dengan konsep purifikasi Muhammad Abduh melalui buletin Al-Manar, kemudian disusul lahirnya Muhammadiyah pada tahun 1912 di Yogyakarta, memantik naluri intelektual Haji Zamzam dan Haji Yunus untuk turut andil dalam perjuangan melawan wabah TBC (Takhayul, Bid'ah, dan Khurafat) yang menjangkiti masyarakat Indonesia saat itu. Diskusi-diskusi tersebut lantas melahirkan konsep organisasi yang bertujuan menangkal penyakit akut tersebut. Tak berselang lama, lahirlah Persatuan Islam (Persis), yang berbasis di Bandung, Jawa Barat.

Konsep tajdid dan purifikasi yang dibawa Persis sudah barang tentu berbenturan dengan faham keagamaan yang kelak secara formal berkembang di masyarakat, yaitu faham yang dikembangkan ulama' tradisionalis melalui organisasi Nahdhatul Ulama'. Secara kronologis waktu, NU memang lahir 3 tahun lebih akhir dibanding Persatuan Islam. Namun, faham keagamaan dan pelestarian budaya lokal yang diusung NU berseberangan dengan faham keagamaan Persis, yang mengusung semangat purifikasi. Seiring perjalanan waktu, Persis berkembang cepat. Kunci sukses pendistribusian

\footnotetext{
${ }^{2}$ Wawancara Pribadi dengan Ketua Pimpinan Wilayah Persatuan Islam Riau Ust. Yana Mulyana, S.Pd.I, pada 22 September 2018.
}

ideologi, gagasan, dan faham organisasi terletak pada kemampuannya ngemong, mengatur, mengelola, dan membimbing masyarakat dengan baik.

Perbedaan Persis dari ormas
lain, seperti NU dan
Muhammadiyah, tentu bukan perkara
aneh. Dakwah Islamiyah di
Indonesia memang berkembang
pesat, bertransformasi, dan
berkompetisi satu sama lain guna
mempertahankan kelanjutan nasib
umat Islam. Corak dakwah yang
sangat variatif dari pelbagai
organisasi keagamaaan tersebut
membentuk pola, metode, strategi,
dan respon yang berbeda-beda pula.
Sebab, dakwah dalam terminologi
Islam itu sendiri berarti ajakan
kepada orang-orang, baik individu,
kelompok, masyarakat, maupun
bangsa ke jalan Allah, ${ }^{3}$ atau untuk
berbuat keabaikan dan menghindari
keburukan. ${ }^{4}$

Persis sebagai organisasi dakwah menerapkan metode dan strategi yang fokus dan berpusat pada tajdid (pembaruan) dan purifikasi. Strategi ini menarik minat umat muslim Indonesia untuk mengikuti, memahami, dan menghayati faham keagamaan Islam melalui Persis. ${ }^{5}$

Dinamika sosial-politik Indonesia pasca reformasi tahun

${ }^{3}$ Al Qur'an Surah An Nahl ayat 125, https://quran.com/16, diakses 18 September 2018.

${ }^{4}$ Al Qur'an Surah Ali Imron 104, https://quran.com/3, diakses 18 September 2018.

5 Wawancara dengan ustadz Yana Mulyana Ketua Umum Persis Riau, pada 22 September 2018. 
1998 silam memiliki andil besar terhadap mobilitas gerakan sosial keagamaan di Indonesia. Ormasormas keagamaan semakin variatif. Persis semakin bergairah dengan berusaha mendistribusikan faham keagamaannya tidak hanya di kalangan intelektual saja. Dalam beberapa tahun terakhir, pendirian pimpinan cabang dan wilayah di luar pulau Jawa semakin pesat, termasuk Persis Wilayah Riau.

Persis Riau memiliki dinamika lokalnya tersendiri. Wacana tajdid menjadi strategi ampuh PW Persis Riau dalam merekrut jama'ah, yang berasal dari pelbagai daerah di Provinsi Riau. Menurut pengakuan Ust. Yana Mulyana Ketua PW Persis Riau masa jihad 2015-2020, "Pesis Riau mengembangkan wacana dakwah dari Pimpinan Pusat Persis terkait tajdid. Namun, Persis Riau memiliki beberapa metode yang berbeda dibanding Persis Pusat, terlebih dalam mendistribusikan gagasan kepada masyarakat. Salah satunya adalah pengorganisasian para pemuda dan mahasiswa di bawah payung HIMA (Himpunan Mahasiswa) Persis. Dengan begini, distribusi gagasan dapat tersampaikan secara maksimal."6

Dudung Abdul Rahman mengatakan, "Seyogyanya Persis mengembangkan kebebasan berfikir dan mengahargai perbedaan sepanjang pendapat itu memiliki dalil, argumentatif, dan berada pada koridor yang jelas, jika memang

${ }^{6}$ Wawancara Pribadi dengan Ketua Pimpinan Wilayah Persatuan Islam Riau Ust. Yana Mulyana, S.Pd.I, pada 22 September 2018.
Persis bergerak di bidang pembaruan pemikiran keislaman serta membuka pintu ijtihad selebar-lebarnya sampai kapan pun." 7

Salah satu pertimbangan mendasar didirikannya Persis di Provinsi Riau adalah kondisi masyarakat yang masih sangat kental dengan sinkretisme dalam pemahaman dan pengamalan ajaran Islam. Masih banyak masyarakat yang percaya dengan kekuatan benda-benda yang dianggap memiliki kekuatan mistik. Mereka juga meminta bantuan pada orang yang sudah mati, yang jelas sangat bertentangan dengan ajaran Islam. Hal inilah yang menjadi motivasi dan tujuan utama kegiatan dakwah Persis, yakni menghapuskan semua pengamalan keagamaan yang tidak sesuai sumber ajaran Islam, sekaligus menanamkan pemahaman ajaran Islam secara lebih baik dan mendalam kepada masyarakat Provinsi Riau. ${ }^{8}$

Persentuhan Persis Riau dengan kebudayaan lokal masyarakat menjadi tidak terelakkan lagi. Setiap agama, termasuk Islam, pasti mengalami kontak dengan kebudayaan lokal. Perjumpaan agama dengan budaya lokal secara teoritis mengambil banyak bentuk. Pertama, mengalami benturan (clash) di mana budaya setempat dihabisi/dihapus sama sekali atas nama larangan agama. Kedua, membuka jalan akomodatif, di mana

7 Dudung Abdul Rahman, dkk, Pergulatan Pemikiran Kaum Muda Persis, (Bandung: Granada, 2005), 86.

${ }^{8}$ Wawancara pribadi dengan Ketua Pimpinan Wilayah Persis Riau Ust. Yana Mulyana, S.Pd.I, pada 20 September 2018. 
pertemuan antara agama dan budaya lokal saling mengisi dan tidak saling menjatuhkan. Ketiga, mengambil bentuk hibriditas. Artinya menerima agama tapi hanya sebagian dan sisanya tradisi setempat. Bentuk ini kemudian biasa dikenal dengan misalnya, Islam Jawa, Islam Banjar, Islam Sasak dan sebagainya. ${ }^{9}$

Persis yang dikenal sebagai organisasi dakwah yang cukup ketat dalam menerapkan asas kembali kepada Al Qur'an dan As Sunnah dihadapkan pada persoalan yang sama, yaitu perjumpaannya dengan kebudayaan dan kearifan lokal. Prinsip tersebut membawa kesulitan tersendiri dalam implementasi dakwahnya, terlebih bila tidak dibarengi pemahaman yang total tentang karakteristik keagamaan komunitas muslim lokal di Riau.

$\begin{array}{rlr}\text { Penelitian ini } & \text { adalah } \\ \text { penelitian kualitatif deskriptif }\end{array}$ tentang strategi dakwah Islam oleh Persis Riau dan respon masyarakat terhadapnya. Secara teoritik, Dakwah Islam berarti menyampaikan pesan atau ajaran Islam kepada masyarakat luas, sebagaimana yang dilakukan Nabi Muhammad SAW pada zamannya. Dalam dakwah Islam, setidaknya terdapat 4 (empat) unsur praktek dakwah agar hasil dakwah dapat sesuai dengan yang diharapkan, yaitu (1) pelaku dakwah (da'i), (2) penerima dakwah atau sasaran dakwah (mad'u), materi dakwah (pesan dan ajaran Islam), dan (4) medium dakwah. Namun yang tidak kalah penting, ke-empat

\footnotetext{
${ }^{9}$ Ahmad Baso, Plesetan Lokalitas: Politik Pribumisasi Islam (Jakarta: Desantara, 2003), 3.
}

unsur tersebut harus dibarengi dengan strategi dan metode dakwah yang baik pula. ${ }^{10}$

Dalam menjalankan dakwahnya, Persis Riau menjalankan strategi tertentu. Strategi dakwah adalah suatu rencana yang disusun sedemikian rupa agar pesan-pesan yang disampaikan dapat diterima, dimengerti, dan diikuti oleh mad'u. ${ }^{11}$ Untuk mencapai tuuan, strategi tidak hanya sebagai cara menunjukkan jalan, melainkan harus mampu menunjukkan teknik operasionalnya. Sebab itu, strategi dan metode dakwah sangat erat kaitannya dengan ke-empat unsur yang telah disebutkan di atas. Mengingat dakwah Islam bertujuan menegakkan amar ma'ruf nahiy munkar, pendekatan dakwahnya menggunakan dua cara, yaitu dakwah struktural dan kultural. ${ }^{12}$

Secara struktural maupun kultural, Persis Riau telah menjalankannya. Dakwah struktural adalah aktivitas dakwah yang berada dalam lingkaran kekuasaan. Sedangkan dakwah kultural adalah aktivitas dakwah yang menekankan pendekatan kebudayaan, yang memperhitungkan adat istiadat, memperhatikan nilai-nilai tradisional, dan memanfaatkan seni dan kearifan lokal yang tidak bertentangan dengan ajaran Islam.

${ }^{10}$ Qodry Azizy, "Dakwah Islam di Tengah-tengah Pluralitas Bangsa", Jurnal Ilmu Dakwah, Vol. 23 No. 1, Januari 2003, 1 .

11 Helena Olii, Reportase Radio, (Jakarta: Indeks Kelompok Framedia, 2006), 26.

12 Muhammad Shulthon, Desain Ilmu Dakwah, (Yogyakarta: Pustaka Pelajar, 2003), 18. 
Tujuannya adalah membentuk kehidupan yang Islami. Chamami Zada, "gerakan Islam pasca orde baru ditandai dengan dua corak di atas; struktural dan kultural. ${ }^{13}$

Kesadaran Persis Riau untuk menerapkan berbagai strategi tidak terlepas dari pertimbanganpertimbangan yang dimilikinya. Sebab, Persis berkepentingan untuk menjaga idealismenya tetap survive dalam jangka waktu yang relatif lebih lama. Porter (1998) menekankan bahwa sebuah organisasi akan bertahan lebih lama apabila mampu menjaga hubungan baiknya dengan pelanggan, kompetitor, anggota baru; mampu mengidentifikasi ancaman yang bisa merusak dan peluang yang bisa mengembangkan organisasi; dan mampu merancang sebuah rencana dan mekanisme tertentu untuk merespon perubahan. ${ }^{14}$

Dalam konteks kultur masyarakat Riau, Persis Riau melihat bahwa ide tadjid dan ukhuwah adalah jawaban atau problem solving. Di sini, sebagai organisasi, Persis dapat dikatakan telah berhasil melakukan analisa tentang ancaman, peluang, kelemahan dan kekuatannya. ${ }^{15}$ Persis memiliki ide

13 Chamami Zada, Islam Radikal: Pergulatan Ormas-ormas Islam Garis Keras di Indonesia, (Jakarta: Teraju, 2002), 89.

14 John R. Hudson, "Theories of Management," dalam http://johnrhudson.me.uk, 20 Oktocber 2015, 9. Lihat juga M. E. Porter, Competitive Strategy: Techniques for Analysing Industries and Competitors, (London: Free Press, 1998).

15 Pankaj Ghemawat, "Competition and Business Strategy in Historical pemurnian Islam karena melihat masyarakat Riau masih terhantui oleh praktek-praktek keagamaan yang jauh dari nilai-nilai islam. Namun begitu, pemaksanaan tidak memungkinkan. Perbedaan harus tetap lestari. Karenanya, Persis Riau membutuhkan kerjasama sekalipun harus berbeda secara mendasar dalam beberapa aspek dengan kelompok lain. Keberhasilan Persis Riau dalam menganalisa persoalan dan memecahkannya terbukti dengan adanya 64 ormas berada di bawah satu komando, di bawah arahan Ustad Yana Mulayana, Ketum Persis Riau Masa Jihad 2015-2020.

Dari sinilah, ketertarikan peneliti untuk menganalisa pengaruh strategi dakwah Persi dan respon masyarakat lokal Riau terhadapnya. Rumusan masalah dalam penelitian ini sebagai berikut: (1) Bagaimana kultur muslim di Riau, serta apa motivasi Persatuan Islam turut andil dalam Islamisasi tersebut?, (2) Bagaimana strategi dakwah Pimpinan Wilayah Persatuan Islam (PERSIS) Riau masa jihad 20152020?, (3) Bagaimana respon masyarakat Riau terhadap usaha dakwah Pimpinan Wilayah Persatuan Islam (PERSIS) Riau masa jihad 2015-2020?.

Penelitian ini memiliki beberapa nilai signifikansi yang besar; pertama, memberikan pemahaman lewat perspektif akademis tentang hubungan tradisi dan kultur keagamaan dalam masyarakat dengan strategi dakwah ormas Persis. Kedua, memberikan

Perpective," HBS Comp.\& Strategy Working Paper, No. 798010, 2000, 1-29. 
masukan konstruktif bagi ormas Persatuan Islam terkait strategi dakwah mereka.

\section{Islam, Persis, dan Dinamika Muslim Riau}

Riau merupakan salah satu provinsi di Indonesia yang terdiri dari daerah daratan dan perairan dengan luas $88.672,67 \mathrm{~km} .{ }^{16}$ Islam pertama kali masuk ke Riau sekitar abad ke 7 Masehi. ${ }^{17}$ Seiring berjalannya waktu, Syekh Burhanuddin membuat ajaran Islam semakin dapat diterima oleh masyarakat Riau dengan tangan terbuka. Daerah Kuntu yang berada di pinggir sungai Kampar merupakan titik tolak awal Islamisasi Syekh Burhanuddin. Sungai Kampar kala itu menjadi wahana transportasi bagi para pedagang dan penjelajah. Sungai Kampar adalah simbol peradaban di masa itu. ${ }^{18}$

Selain sebagai salah satu pusat penyebaran agama islam, Kuntu juga daerah pertama di Riau yang berhubungan langsung dengan pedagang-pedangang asing, baik mereka yang datang dari Cina, India, Arab, mupun Persia. Karenanya, daerah lembah sungai Kampar Kiri menjadi penghasil lada terpenting bagi seluruh dunia pada periode 5001400 Masehi. Kampar menjadi kota metropolitan pertama di jamannya.Kampar menjadi gudang penyedia bahan baku rempah-rempah

\footnotetext{
16 Lihat,

https://en.wikipedia.org/wiki/Riau, diakses 23 September 2018.

17 Tim Penulis, Sejarah Riau,

(Pekanbaru: Unri Press, 1977), 23.

18 Azyumardi Azra, Renaissance Islam di Asia Tenggara, (Bandung: Mizan, 1994), 12.
}

dan hasil hutan, sehingga menarik minat bangsa asing untuk singgah di Kampar, sebagai kota yang terbuka untuk dunia luar. ${ }^{19}$

Dalam konteks masyarakat Riau yang muslim dan terbuka semacam ini, Persatuan Islam Wilayah Riau mulai dibentuk pada tahun 2009. Dua tahun kemudian, tepatnya 2011, struktur kepengurusan dibuat. Tokoh pertama yang mempelopori dakwah Persis di Riau adalah Ust. Yana Mulyana. ${ }^{20}$ Yana adalah sosok sentral yang mengemban dakwah Pesis degan komitmen dan dedikasi tinggi. Sosoknya secara pribadi mendorong respon positif dari masyarakat Riau. Sehingga tidak jarang anggotaanggota Persis dari Pimpinan Pusat turun tangan untuk mengisi berbagai kegiatan dakwah Persis Riau, di antaranya Ust. Prof. Dr. Maman Abdurrahman. ${ }^{21}$

Melihat kondisi jama'ah yang kian lama semakin bertambah, kondisi masyarakat Riau yang membutuhkan pengembangan dakwah, dan perlunya proses kaderisasi sebagai wujud program kerja sebuah organisasi, Pengurus Persis Riau membentuk tim baru yang berasal dari kalangan mahasiswa. Organisasi baru ini bernama Himpunan Mahasiswa (HIMA) Persis, yang bertujuan

\footnotetext{
19 Tim Penulis, Sejarah Riau, (Pekanbaru: Unri Press, 1977), 23.

20 Wawancara pribadi dengan Ketua Bidgar Dakwah Pimpinan Wilayah Persis Riau Ust. Syarifuddin, S.Pd.I, pada 19 September 2018.

${ }^{21}$ Wawancara pribadi dengan salah satu anggota/jama'ah Persis Riau, pada 19 September 2018.
} 
menyiapkan anak-anak muda sebagai penerus tongkat estafet perjuangan Persis di Riau kelak. ${ }^{22}$

Persis Riau di bawah asuhan Ust. Yana Mulyana mengemban visi, misi, serta tujuan dakwah yang sama dengan Persis Pusat, yaitu mengembalikan Islam kepada ajaran Al Qur'an dan As Sunnah. Dalam berdakwah, Persis Riau menghadapi problema-problema berat. Gagasan pembaruan Islam (tajdid) menjadi semakin berat. Pasalnya, Riau merupakan daerah yang kaya akan akulturasi budaya; antara agama dan lokalias, adat dan tradisi, yang menurut pandangan Persis menyimpang dari ajaran Islam yang murni. $^{23}$

Kompleksitas semacam ini bisa ditarik akar historisnya secara lebih jauh. Sejak awal, Persis memang selalu berbenturan dengan lokalitas yang dianggap menyimpang dari Islam murni. A. Hassan berbenturan dengan KH. Wahab Hasbulloh, misalnya, terkait lokalitas berupa taqbil, yaitu tradisi mencium tangan kepada figure tokoh yang dihormati. ${ }^{24}$

Selain soal taqbil yang sudah tercatat dalam sejarah, pergesekan Persis Riau dengan kaum tradisonalis

22 Wawancara pribadi dengan Ketua Pimpinan Wilayah Persis Riau Ust. Yana Mulyana, S.Pd.I, pada 19 September 2018.

23 Wawancara pribadi dengan Ketua Pimpinan Wilayah Persis Riau Ust. Yana Mulyana, S.Pd.I, pada 19 September 2018.

24 Wawancara pribadi dengan Ketua Pimpinan Wilayah Persis Riau Ust. Yana Mulyana, S.Pd.I, pada 19 September 2018. juga terjadi dalam diskursus zaiarah kubur dan tawassul, sebagaimana pernyataan dari Ust. Mukhtar Pengurus Persis Kabupaten Kuansing. Mukhtar mengatakan, "Tawassul versi Persis berbeda dengan tawassul versi kaum tradisionalis. Persis masih menerima tawassul sebagai fadhail al a'mal, namun membatasinya dengan kriteria tertentu, seperti tawassul dapat dilakukan jika orang yang ditawassul-i itu masih hidup, sebagaimana sunnah Nabi Muhammad SAW. Sedangkan kaum tradisionalis memandang tawassul dapat dilakukan, baik melalui orang yang masih hidup maupun yang sudah meniggal.,"25

Walaupun harus diakui bahwa konfrontasi Persis dan ulama tradisionalis yang mendukung pelestarian budaya lokal berbedabeda. Sebab, benturan macam ini diperparah oleh persoalan demografis. Dakwah Persis di Riau bila dibanding dengan dakwah di Jawa, tidak terlalu sulit. Persis Riau tidak menghadapi konfrontasi sebanyak saat dakwahnya dijalankan di pulau Jawa. Dakwah Persis di Riau relatif lebih sejalan dengan Muhammadiyah. Sementara di Jawa, sebagai pusat dan basis massa kaum tradisionallsi, Persis berhadapan langsung dengan kaum tradisionalis, mulai dari level ranting hingga level pusat. Sehingga, probabilitas konfrontasinya semakin terbuka lebar dan jauh lebih kompleks. Namun demikian, bukan berarti Persis Riau tidak menghadapi

25 Wawancara dengan Pengurus Cabang Persis Kuansing Ust. Mukhtar, pada 19 September 2018. 
persoalan konfrontasi saat menyebarkan ide tajdid atau pembaruan tersebut. ${ }^{26}$

Problema masyarakat yang kompleks tersebut, terlebih terkait sikap ormas terhadap kebiasaan masyarakat ini, memunculkan sikap dan sekaligus memberi kesadaran baru tentang pentingnya menjalin ukhuwah (persaudaraan) antar orang muslim. Ide ukhuwah ini lantas menjadi senjata paling ampuh dan strategi paling jita bagi Persis Riau untuk mensukseskan gagasan dakwahnya, ide tajdid. Dengan ide ukhuwah ini, jama'ah Persis di Riau semakin bertambah.

Bukti paling nyata, dalam bidang politik dan sosial sebagai contoh kecil, Ustadz Yana Mulyana yang masih tercatat sebagai Ketua PW Persis Riau dipercaya oleh masyarakat Riau untuk menjabat Ketua Gerakan Masyarakat Menuntut Keadilan (GMMK), yang membawahi 63 organisasi masyarakat. ${ }^{27}$ Kepercayaan publik yang berasal dari berbagai ormas berbeda ini adalah buah manis strategi dan gagasan ukhuwah. Ustadz Yana mengutip suatu kalimat sederhana tapi sangat bertenaga, "mari kita bersepakat untuk hal-hal yang tidak kita sepakati."

Melalui strategi ukhuwah, dengan merangkul berbagai pihak yang memiliki kepentingan sama, mengantarkan Persis Riau dipercaya

26 Wawancara dengan Pengurus Persis Wilayah Pekanbaru Ust. Zaki, pada 18 September 2018.

27 Wawancara pribadi dengan Ketua Bidgar Dakwah Pimpinan Wilayah Persis Riau Ust. Yana Mulyana, S.Pd.I, pada 19 September 2018. oleh masyarakat Riau. Ide ukhuwah menjadi energi yang mampu menembus batas perbedaan organisasi, menghilangkan warna individu dan kelompok, sehingga semua golongan bersatu dan bersekutu untuk mewujudkan satu nilai bersama yang didukung oleh semua kepentingan. ${ }^{28}$

Untuk menopang ideologi besarnya, PW Persis Riau memiliki ragam kegiatan dan dakwah sosial, di antaranya seperti pengajian harian, bulanan, tahunan, Khutbah Jumat, Ied, Gerhana, diskusi, kajian penerimaan dan penyaluran zakat mal, fitrah, maupun kurban ternak Idul Adha, dan lain-lainnya. Peran besar Persis Riau di dalam masyarakat ini dan keberpihak Persis Riau atas kepentingan publik menjadikan mereka menaruh simpati, tertarik untuk ikut andil dan berperan dalam upaya-upaya pengembangan organisasi Persatuan Islam di Riau. Basis Persis Riau menjadi solid dan kokoh. Sehingga, gerakan dakwah, sosial, pendidikan, dan politik dapat dirancang dengan lebih sistematis, terorganisir, satu komando, dan tidak saling bergesekan satu sama lain, serta tetap dalam garis perjuangan cita-cita awal didirikannya Persis. Strategi menjalin ukhuwah sangat ampuh merekatkan tali persaudaraan tersebut. $^{29}$

28 Wawancara pribadi dengan Ketua Bidgar Dakwah Pimpinan Wilayah Persis Riau Ust. Syarifuddin, S.Pd.I, pada 20 September 2018.

29 Wawancara pribadi dengan Ketua Bidgar Dakwah Pimpinan Wilayah Persis Riau Ust. Syarifuddin, S.Pd.I, pada 20 September 2018. 


\section{Strategi Dakwah Pimpinan Wilayah Persatuan Islam Riau}

Sejak awal kedatangannya, Islam sudah tumbuh dan berkembang dalam situasi yang tidak hampa budaya. Demikian pula yang terjadi di Nusantara, dakwah yang dilakukan oleh para penyebar Islam pada masa awal telah menunjukkan Islam yang akomodatif terhadap tradisi masyarakat setempat. Melalui metode dakwah akomodatif tersebut, Islam tidak dipandang sebagai ancaman bagi eksistensi kebudayaan lokal yang telah ada sebelumnya, sehingga ajarannya mudah diterima oleh publik. ${ }^{30}$

Pemahaman terhadap kondisi sosio kultural suatu masyarakat jelas membawa pengaruh signifikan terhadap keberhasilan sebuah upaya dakwah. Pemahaman yang komprehensif tentang karakter masyakarat adalah pertimbangan utama dalam menentukan strategi dakwah. Strategi dakwah dapat dirumuskan secara tepat ketika sebuah organisasi atau lembaga dakwah mampu mengenali dan memahami obyek dakwahnya dengan baik, termasuk memahami seting kultur-keagamaan yang melingkupi kehidupan sebuah komunitas masyarakat. ${ }^{31}$

30 Muhammad Harfin Zuhdi, "Dakwah dan Dialektika Akulturasi Budaya", dalam jurnal RELIGIA Vol. 15 No. 1, April 2012, 46-64.

31 Strategi adalah keseluruhan keputusan kondisional tentang tindakan yang akan dijalankan, guna mencapai tujuan, lihat Anwar Arifin, Dakwah Kontemporer Sebuah Studi Komunikasi (Yogyakarta: Graha Ilmu, 2011), 227. Sedangkan Strategi dakwah merupakan
Hal tersebut penting dilakukan karena setiap perilaku keagamaan obyek dakwah merupakan representasi dari cara mereka memahami ajaran agama. Memasukkan seting kultur keagamaan obyek dakwah sebagai bahan pertimbangan dalam merumuskan strategi dakwah akan menghasilkan strategi yang efektif dan efisien dalam level implementasinya. ${ }^{32}$

Perumusan strategi dakwah Persis dilakukan saat Tasykil sekaligus rapat kerja PW Riau. Yaitu, sekitar satu minggu setelah kepengurusan PW Persis Riau masa jihad 2015-2020 terbentuk. Target utama dakwah Persis Riau adalah tercapainya peningkatan wawasan, pemahaman, dan keyakinan para anggota dan umat Islam, khususnya yang berada di Riau, terhadap ajaran Islam secara kaaffah, baik di bidang aqidah, ibadah, dan muamalah yang sesuai dengan Al Qur'an dan As Sunnah. ${ }^{33}$

Secara filosofis, Persis memiliki pandangan prinsipil dalam memahami dakwah secara umum.

suatu proses penentuan cara dan upaya untuk menghadapi sasaran dakwah dalam situasi dan kondisi tertentu guna mencapai tujuan dakwah dengan memanfaatkan berbagai sumber daya yang ada, lihat Awaludin Pimay, Paradigma Dakwah Humanis: Strategi dan Metode Dakwah Prof. KH. Saifuddin Zuhri, (Semarang: RaSail, 2005), 50.

32 Bambang Hariadi, Strategi Manajemen, Strategi Memenangkan Perang Bisnis, (Malang: Bayu Media Publishing, 2005), 5.

33 Wawancara pribadi dengan Ketua Bidgar Dakwah Pimpinan Wilayah Persis Riau Ust. Syarifudin, S.Pd.I, pada 20 September 2018. 
Sekalipun Persis berseberangan dengan organisasi tradisionalis seperti Nahdhatul Ulama, bukan berarti Persis serupa dengan organisasi modernis seperti Muhammadiyah. Persis menjelma menjadi organisasi yang konsern terhadap ajaran Islam yang murni, dan menjadi organisasi yang paling menetang praktik bid'ah, khurafat, dan takhayul, dibandingkan organisasi Muhammadiyah dan alIrsyad. Ciri khas dari gerakan dakwah Persis Riau adalah menitikberatkan pada pembentukan pemahaman keagamaan yang dilancarkan melalui pendidikan, kajian, diskusi, seminar, dan perdebatan-perdebatan ilmiahakademik.

Aktifitas semacam ini menjadikan Persis berbeda dengan Muhammadiyah — sesama organisasi modernis-yang lebih banyak bergerak dalam bidang sosial dan pendidikan. Hal yang membedakan dari keduanya, juga terlihat dari strategi dakwahnya. Muhammadiyah lebih mengutamakan penyebaran pemikiran-pemikirannya dengan lebih tenang dan damai. Sedangkan Persis lebih senang dengan perdebatan dan polemik. Persis memiliki pandangan bahwa dalam masalah agama tidak ada istilah kompromi. Apa yang dipandang tidak benar menurut dalil Al Qur'an dan As Sunnah, secara harus tegas ditolak. Sedangkan apa yang dianggap benar harus disampaikan walaupun pahit. $^{34}$

34 Dadan Wildan Anas, dkk, Perjalanan Sejarah Persatuan Islam, dalam Anatomi Gerakan Dakwah Persatuan Islam, (Tangerang: Amana Publishing, 2015), 20.
Ketegasan-kegetasan yang sangat prinsipan di atas berdasarkan pada berbagai bahan pertimbangan utama. Dalam proses perumusan strategi dakwah, PW Persis Riau dapat dirangkum menjadi dua hal utama. Pertama, pendidikan. Hal itu lantaran jumlah peserta didik yang berasal dari dalam dan luar jam'iyyah sangat antusias dan terus berkembang, sehingga memicu PW Persis Riau meningkatkan kualitas mutu pendidikan sekolah, pesantren dan masjid yang mereka kelola. Strategi lewat jalur pendidikan ini terbukti ampuh, dimana dakwah Persis di bidang aqidah, ibadah, dan muammalah semakin diterima dan dipahamai masyarakat luas.

Kedua, penyediaan fasilitas dakwah yang memadai. PW Persis Riau membawahi banyak Pimpinan Jamaah yang tersebar di setiap daerah di Provinsi Riau. Realitas ini mengharuskan organisasi untuk melakukan optimalisasi terkait media dan wadah dakwah mereka. Karenanya, tidak heran apabila berbagai media lokal, seperti radio dan televisi menjadi media yang mereka manfaatnya. Media dakwah Persis pun tidak terbatas pada literasi saja, melainkan juga menggunakan panggung debat, media telekomunikasi modern, seperti radio, televisi dan internet. ${ }^{35}$

Melihat strategi dan gerakan Persis yang kian inovatif ini, tidak saja publik dan pengikut fanatik, tetapi pemerintah pun turut mengapresiasinya. Terbukti,

35 Wawancara pribadi dengan Ketua Bidgar Dakwah Pimpinan Wilayah Persis Riau Ust. Syarifudin, S.Pd.I, pada 20 September 2018. 
Kementerian Kominfor khususnya memberikan dukungan penuh terhadap program kerja dari Persis tersebut, yaitu upaya untuk meluaskan gerakan dakwah Islam melalui media digital. ${ }^{36}$

Program-program Persis, strategi dakwah dan ranah-ranah yang jadi lahan garapan seperti di atas bukan perkara baru. Sebab, Persis tetap konsisten dengan sejarah perjuangannya. Gerakan literasi Persatuan Islam telah dimulai sejak tahun 1931, dengan menerbitkan majalah khusus yang membincang seputar problema-problema agama, tanpa menantang pihak-pihak bukan Islam. Majalah ini bernama $\mathrm{Al}$ Fatwa, yang ditulis dengan huruf arab jawi (pegon), agar mudah dikonsumsi oleh kalangan muslim di Sumatera, Malaysia, dan Kalimantan. Namun sayangnya produksi majalah ini berhenti pada tahun 1933, dan digantikan oleh majalah Al Lisan pada tahun 19351942. Gerakan literasi Persis terus berkembang, dengan kemunculan majalah-majalah yang memuat pemikiran-pemikiran tokoh intelektual Persis hingga kini (2018). ${ }^{37}$

Kader-kader Persis sangat yakin betul tentang manfaat besar yang dipetik dari optimalisasi fasilitas dan media dakwah. Bahkan,

\footnotetext{
36 Wawancara dengan

Abdurrahman Mawazi, pengamat sosial keagamaan sekaligus dosen STAIN Sultan Abdurrahman, Kepulauan Riau, 24 November 18.

37 Wawancara pribadi dengan

Ketua Bidgar Dakwah Pimpinan Wilayah

Persis Riau Ust. Syarifuddin, S.Pd.I, pada 20

September 2018.
}

Ajat Sudrajat mengatakan bahwa menggunakan perkembangan teknologi di era digital demi kepentingan dakwah Persis, menciptakan kader-kader yang qurani dan umat muslim yang bertakwa, adalah strategi yang luar biasa. Persis melihat bahwa para dai dan mubalig harus bisa menjadikan media sosial sebagai saluran dakwah dan membangun strategi dakwah melalui saluran itu agar syiar Islam bisa tersampaikan dengan baik. ${ }^{38}$ Dai dan mubaligharus memiliki pemahaman dan wawasan luas mengenai teknologi informasi dan media sosial untuk bisa berdakwah menggunakan saluran itu sesuai dengan rambu-rambu dalam dunia internet. Persis selama ini sudah menjalankan dakwah digital melalui saluran PersisTV di YouTube serta laman resmi organisasi. ${ }^{39}$

$\begin{array}{ccr}\text { Strategi } & \text { dakwah } & \text { dengan } \\ \text { pendekatan } & \text { pendidikan } & \text { dan }\end{array}$ optimalisasi medium dakwah sangat efektif. Sebab, Persis dengan begitu dapat merambah ranah-ranah lain dengan tetap mempertahankan pendekatan prinsipil tersebut. Hal itu bisa terlihat bagaimana Persis ingin berdakwah di dunia bisnis dan penguatan ekonomi ekonomi umat. Persis meyakini bahwa ekonomi dan bisnis pun bagian dari ibadah mereka. Di tangan Persis, urusan ekonomi dan dunia bisnis tidak semata menjadi materialistik an-sich, tetapi bisa dipahami sebagai ibadah yang mengandung kepentingan

\footnotetext{
${ }^{38}$ Ajat Sudrajat. "Persis optimalkan dakwah digital," dalam https://www.msn.com, 27 Oktober 2018.

39 Hal senada juga disampaikan oleh ustad Yana Mulyana, interview 23 November 18.
} 
ukhrawi. Konsep inilah yang diapresiasi dengan sangat positif oleh publik. $^{40}$

Yana Mulyana melalui program pemberdayaan ekonomi kerakyatan yang berbasis kultur sosial masyarakat Riau, menyediakan lahan sekitar 1000 Hektar guna ditanami kelapa sawit. Adapun pengelolaannya sepenuhnya diserahkan kepada jamaah dan masyarakat sekitar kebun sawit. Harapannya, hasil dari pertanian tersebut dapat mencukupi anggaran kerja dari organisasi Persis, juga dapat membantu perekonomian masyarakat Riau. Dengan begitu, citra positif Persis di Riau mengalami signifikansi yang baik. Bahkan masyarakat Riau mengapresiasi upaya Persis dalam penguatan ekonomi kerakyatan tersebut. $^{41}$

\section{Respon Masyarakat terhadap Dakwah Persis Riau}

Dalam proses dakwah, respon datang dari para mad'u. Dakwah yang disampaikan oleh seorang da' $i$ dengan metode ceramah tertentu akan menimbulkan reaksi bermacammacam dari mad'u. Reaksi yang terjadi pada mad'u ini disebut dengan respon. Respon dapat bersifat positif dan negatif. Terdapat beberapa perdebatan diantara para akademisi dalam memandang istilah respon. Perdebatan tersebut mengarahkan kita pada kekayaan

40 Wawancara dengan Lukman, salah satu pelaku bisnis dan UMKM di Batam, 25 November 18.

${ }^{41}$ Wawancara dengan Ketua HIMA Persis Riau, 23 September 2018. makna suatu kata. Scheerer mengatakan, "Respon adalah proses pengorganisasian rangsang. Rangsang proksimal diorganisasikan sedemikian rupa hingga terjadi representasi fenomenal dari rangsang proksimal tersebut. ${ }^{42}$

Representasi dibentuk dari respon terhadap suatu fenomena. Respon adalah proses yang berlangsung rutin dan tidak terputus. Proses ini membentuk suatu diskursus tentang tanggapan individu terhadap suatu fenomena. Respon terkait erat dengan komunikasi, karena respon merupakan suatu kegiatan dari organisme yang semata-mata bukanlah suatu gerakan yang positif. Setiap kegiatan ditimbulkan oleh perangsang yang disebut dengan respon. ${ }^{43}$

\begin{tabular}{lrr}
\multicolumn{1}{c}{ Jalaludin } & Rakhmat \\
mengatakan, & "Respon atau \\
tanggapan dapat diartikan sebagai \\
hasil atau kesan yang didapat dari \\
pengamatan tentang subjek, \\
peristiwa, atau hubungan-hubungan
\end{tabular} yang diperoleh dengan menyimpulkan informasi dan menafsirkan pesan-pesan. ${ }^{44}$ Karenanya, respon terbentuk dari proses rangsangan, atau pemberian aksi, atau sebab terhadap subjek peristiwa yang berujung pada hasil

${ }^{42}$ Lihat pernyataan Scheerer dalam Sarlito Wirawan Sarwono, Teori-teori Psikologi Sosial, (Jakarta: PT. Raja Grafindo Persada, 2005), 87.

${ }^{43}$ Lihat pernyataan Scheerer dalam Sarlito Wirawan Sarwono, Teori-teori Psikologi Sosial, (Jakarta: PT. Raja Grafindo Persada, 2005), 87

44 Jalaludin Rakhmat, Psikologi Komunikasi, (Bandung: Remaja Rosda Karya, 1999), 51. 
kreasi dan akibat dari proses rangsangan tersebut.

Strategi dakwah Persis yang mengedepankan tajdid dan purifikasi lantas membentuk kanal-kanal baru (pendidikan dan penggarapan seluruh medium dakwah) dalam upaya mengoptimalisasi pun mendapat responnya dari mad'u. Keterlibatan aktif PW Persis Riau dalam ranah sosial-politik telah diinisiasi oleh Ust. Yana Mulyana yang menjabat sebagai Ketua GMMK (Gerakan Masyarakat Menuntut Keadilan). Sepak terjangnya diakui oleh pemerintah, ormas sosial, ormas agama, dan lain sebagainya. Sehingga dalam titik ini, Persis berhasil mengambil simpatik positif dari masyarakat Riau, khususnya yang masih dalam belenggu ketertindasan dan ketidakadilan. ${ }^{45}$

Konsep keadilan sangat erat dengan rasa nasionalisme dalam kehidupan bernegara. Mengingat, Persis melalui $M$. Natsir tercatat dalam sejarah sebagai organisasi yang memiliki perhatian besar terhadap kecintaan tanah air Indonesia. Pendidikan sekolah yang diinisiasi Persis, selain memakai kurikulum ideologis Persis, tetapi juga tetap menggunakan kurikulum dari pemerintah melalui dinas pendidikan.

Hal ini sebagai jembatan Persis dalam mengaktualisasikan pemikiran M. Natsir sebagai seorang negarawan dan tokoh Persis yang cinta tanah air. Meski dakwah tajdid

45 Wawancara pribadi dengan Ketua Pimpinan Wilayah Persis Riau Ust. Yana Mulyana, S.Pd.I, pada 20 September 2018.
Persis terkenal keras, dan tanpa kompromi, namun itu hanya sebatas dalam diskusi dan perdebatan, dan tidak mengarah pada perbuatan menyakiti secara fisik, lebih-lebih melakukan tindakan radikal dan kiminal. ${ }^{46}$

Sepak terjang PW Persis di Riau yang sangat peduli terhadap keadilan, nasionalisme, diskusi dan debat yang santun ini mendapat jawaban dari masyarakat luas. Jamaah pengajian yang diadakan PW Persis semakin penuh. Citra positif terhadap ajaran Persis lambat laun semakin kentara. Bahkan, terdapat salah satu kampong di Provinsi Riau yang menamakan dirinya kampong Salafi model Persis. ${ }^{47}$

Secara umum, di bidang keagamaan, masyarakat menilai bahwa Persis berdakwah demi tujuan menciptakan generasi Qurani, yaitu generasi muslim yang berperilaku sesuai asas-asas dan nilai-nilai alQuran. Publik mengapresiasi perjuangan Persis dengan pertimbangan bahwa generasi millenial telah jauh dari nilai-nilai Islami. Untuk itulah, gerakan Persis dalam rangka menjadikan generasi ini sebagai generasi Qurani merupakan perkara urgen yang

46 Wawancara pribadi dengan Ketua Pimpinan Wilayah Persis Riau Ust. Yana Mulyana, S.Pd.I, pada 20 September 2018.

47 Wawancara pribadi dengan Ketua Pimpinan Wilayah Persis Riau Ust. Yana Mulyana, S.Pd.I, pada 20 September 2018. 
dinanti-nantikan oleh masyarakat muslim. ${ }^{48}$

Sementara itu, Persis yang terus mengembangkan strategi dakwah digital dan memanfaatkan media sosial yang ada, bagi generasi millenial yang akrab dengan internet, hal itu sangat positif. Melihat strategi dan gerakan Persis yang kian inovatif ini, tidak saja publik tetapi juga pemerintah turut mengapresiasinya, Kementerian Kominfo khususnya juga turut memberikan dukungan penuh terhadap program kerja dari Persis. Kominfo berharap Persis terus meluaskan gerakan dakwah Islam melalui media digital. ${ }^{49}$

Di bidang ekonomi, masyarakat menilai Persis juga aktif berdakwah melalui bidang ekonomi dan bisnis, dengan menyakininya sebagai bagian dari ibadah. Apresiasi paling positif terhadap strategi dakwah Persis bisa terlihat dari bagaimana publik menilai konsep ekonomi dan bisnis di bawah payung semangat ibadah yang Persis tawarkan. Di tangan Persis, urusan ekonomi dan dunia bisnis tidak semata menjadi materialistik an sich, tetapi bisa dipahami sebagai ibadah yang mengandung kepentingan ukhrawi. Konsep inilah yang diapresiasi dengan sangat positif oleh publik. $^{50}$

\footnotetext{
${ }^{48}$ Wawancara dengan Ketua Pesistri Ustadzah Okti, pada 18 September 2018.$$
49 \text { Wawancara dengan }
$$

Abdurrahman Mawazi, pengamat sosial keagamaan sekaligus dosen STAIN Sultan Abdurrahman, Kepulauan Riau, 24 November 18.

50 Wawancara dengan Lukman, salah satu pelaku bisnis dan UMKM di Batam, 25 November 18.
}

Citra positif Persis dalam pandangan masyarakat tidak terbatas di Riau, melainkan telah menyebar ke daerah-daerah lain, baik basis massa dari Persis maupun non-basis. Kenyataan ini membawa angin segar perubahan persepsi publik, bahwa Persis merupakan satu dari sekian banyak organisasi masyarakat yang peduli terhadap kelangsungan dan kejayaan umat Islam Indonesia menggunakan konsepsi ukhuwah. ${ }^{51}$

Banyak apresiasi yang ditujukan pada Persis. Salah satu apresiasi tersebut datang dari Direktur Jenderal Bimbingan Masyarakat (Bimas) Islam Kementerian Agama Abdul Jamil yang berharap agar Persatuan Islam (Persis) menggarap perekonomian umat. Bagi Abdul Jamil, Persis perlu berpartisipasi bagi terwujudnya kejayaan ekonomi bangsa. ${ }^{52}$

Hal yang paling penting dan paling menyedot perhatian untuk dibicarakan, sejatinya, adalah respon masyarakat terhadap aspek keberpihakan Persis secara politik, sekalipun Persis bukan ormas politik. Masyarakat menilai, Persis memiliki visi politis yang fleksibel. Persis bukan partai politik ataupun organisasi massa yang menekankan pentingnya tujuan politik. Namun, bukan berarti Persis tidak memiliki visi-misi politis. Karenanya, sekali

51 Wawancara pribadi dengan Pengurus Persis wilayah Pekanbaru Ust. Zaki, 24 September 2018.

52 Disampaikan pada Musyawarah Kerja Nasional III Pimpinan Pusat Persis, Jumat (30/11/2012) di Bandung, Jawa Barat. Lihat Dedi Muhtadi, "Persatuan Islam Perlu Menggarap Sektor Ekonomi", https://nasional.kompas.com, 1 Desember 2012. 
pun Persis fokus pada pendidikan dan dakwah, ia tetap memiliki nilainilai politis yang diperjuangkan. Kemampuan Persis mengkombinasikan kepentingan memperjuangkan Islam dalam atmosfer demokrasi. Di tangan Persis, Islam dan demokrasi tidak melahirkan kontradiksi yang anarki.

Dalam konteks politik dan kebangsaan, Persis merupakan salah satu organisasi yang percaya bahwa Islam adalah pedoman hidup dalam segala aspek. Ust. Yana Mulyana menjabarkan makna dari jihad umum Persis yang mengandung seruan tentang pentingnya melaksanakan amar ma'ruf dan nahi munkar dalam segala ruang dan waktu, pentingnya membela dan menyelamatkan umat Islam dari gangguan lawan-lawan Islam, tetapi semua itu harus ditempuh dengan cara yang $h a q$ dan ma'ruf, serta sesuai dengan ajaran Al Qur'an dan As Sunnah. ${ }^{53}$

Bagi Ustad Yana Mulyana, yang terpenting bagi umat muslim adalah persatuan (ukhuwah). Visi persatuan umat muslim jauh lebih baik dari pada egosentrisme yang mengarah pada disintegrasi. Kritik dan saran yang ustad Yana sampaikan untuk ormas-ormas di luar Persis yang kebetulan memiliki visi transnasionalisme adalah bahwa perjuangan mereka tidak boleh ahistoris. Memperjuangan Islam di Indonesia tidak boleh keluar dari

53 Wawancara pribadi dengan Ketua Pimpinan Wilayah Persis Riau Ust. Yana Mulyana, S.Pd.I, pada 20 September 2018. akar sejarah yang sudah hidup dan mengakar di bumi Nusantara ini. ${ }^{54}$

Contoh lain adalah saat Ustad Yana Mulyana mendukung gagasan mendirikan Khilafah. Baginya, pendirian negara khilafah adalah keniscayaan. Tetapi, Pancasila dan NKRI adalah kenyataan sejarah yang harus dihadapi. Perlawanan secara anarki dan inkonstitusional melawan undang-undang di Republik Indonesia ini hanya untuk memperjuangkan Khilafah tidak bisa dibenarkan. Cara-cara memperjuangkan tegaknya khilafah dengan jalan yang bathil tidak bisa diterima. Salah satu ciri jalan bathil adalah menentang konstitusi. Karenanya, bagi Yana, perjuangan politik Persis dititipkan kepada partai-partai politik yang sevisi. Inilah jalan konstitusional tersebut. ${ }^{55}$

Sampai di sini dapat dikatakan bahwa pandangan politik Persatuan Islam (Persis) sangat lentur. Persis dapat mengkombinasikan kepentingannya dengan realitas politik yang sedang dominan. Perjuangan menjadikan Islam sebagai dasar negara di bawah bendera khilafah tidak bertentangan dengan suara mayoritas dalam sistem demokrasi. Karenanya, melalui Partai Politik yang memperjuangkan Islam sebagai dasar negara, Persis ikut terlibat memperjuangkan Islam

54 Wawancara pribadi dengan Ketua Pimpinan Wilayah Persis Riau Ust. Yana Mulyana, S.Pd.I, pada 20 September 2018.

55 Wawancara pribadi dengan Ketua Pimpinan Wilayah Persis Riau Ust. Yana Mulyana, S.Pd.I, pada 20 September 2018. 
melalui mekanisme demokrasi dan partai politik yang sah dan legitimit.

Salah satu buah manis dari keterlibatan aktif Persis di dunia politik yang demokratis ini adalah kehadirannya yang diterima oleh publik luas. Bahkan, paa suatu kesempatan, Presiden Joko Widodo menyampaikan sebuah komitmen untuk Persis. Presiden Joko Widodo menyatakan bakal membangun rumah susun untuk Persatuan Islam (Persis), sebuah organisasi Islam yang berusia cukup tua di Indonesia. Pernyataan itu disampaikan oleh Presiden saat mengunjungi Pondok Pesantren Persis di Bambu Apus, Cipayung, Jakarta Timur, Selasa (25/9/2018).

Kita tidak melihat komitmen Presiden terhadap Persis sebagai komitmen politik biasa. Lebih dari itu, juga sebagai keberhasilan Persis menempatkan dirinya dengan visi ideal yang kompatibel dengan atmosfer demokrasi. Bahkan, Presiden mengatakan bahwa Persis janji membangunkan rumah susun untuk Persis tersebut lantaran Persis sebelumnya mengajukan proposal pembangunan tiga rumah susun. Lebih jauh, Presiden juga menyinggung soal rencana pendirian Universitas Persis. Presiden mengatakan Menteri Riset, Teknologi dan Pendidikan Tinggi Mohamad Nasir akan memproses pendirian Universitas Persis itu. ${ }^{56}$

56 Yodie Hardiyan, "Presiden Jokowi Bakal Bangun Rusun Bagi Persatuan Islam," dalam kabar24.bisnis.com, 29 September 2018.

\section{Kesimpulan}

Persis adalah organisasi Islam yang ketat dalam memperjuangkan semangat permurnian, termasuk Persis Riau di bawah masa jihad (kepemimpinan) Ustad Yana Mulayana. Kehadiran Persis di bumi Melayu disambut hangat oleh muslim Melayu yang memiliki jiwa inklusif dan sejarah Islamisasi yang selalu berjalan dengan damai, seperti yang terjadi di Kampar dan sekitarnya. Namun, keberhasilan tersebut tidak bisa dipisahkan dari kombinasi yang apik antara kepemimpinan dan koordinasi yang solid antara Persis Pusat dan Persis Wilayah.

Dengan menekankan pada aspek pengembangan pendidikan Islam, baik melalui sekolah, masjid, musholla, Persis Riau bisa menyentuh seluruh lapisan masyarakat dan memenuhi kebutuhan dasar mereka. Seiring berjalannya waktu, Persis Riau menggarap proyek optimalisasi medium dakwah, yaitu menyediakan fasilitas dakwah yang lebih beragam, luas, dan memanfaatkan segala media yang ada, termasuk dakwah digital dan ranah-ranah pengembangan ekonomi keumatan. Persis Riau mengola lahan-lahan hibah dan wakaf, misalnya, salah satunya untuk pengelolaan kebun sawit.

Aspek politik pun tidak luput dari bidikan program kerja Persis Riau di masa jihad Ustad Yana Mulayana. Dengan membentuk Gerakan Masyarakat Menuntut Keadilan (GMMK), figur Yana Mulyana sebagai Ketua Persis dapat diterima 
oleh setidaknya 63 ormas berbeda. Atas dasar prinsip persaudaraan atau ukhuwah, pribadi Yana menjadi cermin bagi kepentingan bersama yang mengatasnamakan umat muslim.

Secara umum, citra positif masyarakat Riau terhadap gerakan dan strategi dakwah Persis Riau terus berkembang. Mereka tidak saja mendapat layanan pendidikan keagamaan yang optimal, tetapi juga kebutuhan ekonomi dan kepentingan politik terfasilitasi. Strategi dakwah yang bersifat online maupun offline dirasa cocok untuk segala usia dari berbagai lapisan sosial masyarakat Riau.

\section{Daftar Pustaka}

Baso, Ahmad. (2003). Plesetan Lokalitas: Politik Pribumisasi Islam Jakarta: Desantara.

Sudrajat, Ajat. (2018). "Persis optimalkan dakwah digital," dalam https://www.msn.com, diakses tanggal 27 Oktober 2018.

Pimay, Awaludin. (2005). Paradigma Dakwah Humanis: Strategi dan Metode Dakwah Prof. KH. Saifuddin Zuhri. Semarang: RaSail.

Azyumardi, Azra. (1994). Renaissance Islam di Asia Tenggara. Bandung: Mizan.

Hariadi, Bambang. (2005). Strategi Manajemen, Strategi Memenangkan Perang Bisnis. Malang: Bayu Media Publishing.

Zada, Chamami. (2002). Islam Radikal: Pergulatan Ormas- ormas Islam Garis Keras di Indonesia. Jakarta: Teraju.

Anas, Dadan Wildan dkk. (2015). Perjalanan Sejarah

Persatuan Islam, dalam Anatomi Gerakan Dakwah Persatuan Islam. Tangerang: Amana Publishing.

Muhtadi, Dedi (2012). "Persatuan Islam Perlu Menggarap Sektor Ekonomi", https://nasional.kompas.com, diakses tanggal 1 Desember 2012.

Abdul Rahman, Dudung dkk. (2012). Pergulatan Pemikiran Kaum Muda Persis. Bandung: Granada.

Olii, Helena. (2006). Reportase Radio. Jakarta: Indeks Kelompok Framedia.

https://en.wikipedia.org/wiki/Riau, diakses 23 September 2018.

https://quran.com/16, diakses 18 September 2018.

Rakhmat, Jalaludin. (1999). Psikologi Komunikasi.

Bandung: Remaja Rosda Karya.

Hudson, John R. (2015). "Theories of Management," dalam http://johnrhudson.me.uk, diakses pada tanggal 20 Oktocber 2015.

Porter, M. E. (1998). Competitive Strategy: Techniques for Analysing Industries and Competitors. London: Free Press.

Zuhdi, Muhammad Harfin. (2012) "Dakwah dan Dialektika Akulturasi Budaya", dalam jurnal RELIGIA, Vol. 15 No. 1, April 2012. 
Shulthon, Muhammad. (2003). Desain Ilmu Dakwah. Yogyakarta: Pustaka Pelajar. Ghemawat, Pankaj. (2000). "Competition and Business Strategy in Historical Perpective," dalam HBS Comp.\& Strategy Working Paper, No. 798010.

Azizy, Qodry. (2003). "Dakwah Islam di Tengah-tengah Pluralitas Bangsa", Jurnal Ilmu Dakwah, Vol. 23 No. 1.

Sarwono, Sarlito Wirawan. (2005). Teori-teori Psikologi Sosial. Jakarta: PT. Raja Grafindo Persada.

Arifin, Anwar. (2011). Dakwah Kontemporer Sebuah Studi Komunikasi. Yogyakarta: Graha Ilmu.

Tim Penulis. (1977). Sejarah Riau. Pekanbaru: Unri Press.

Hardiyan, Yodie. (2018). "Presiden Jokowi Bakal Bangun Rusun Bagi Persatuan Islam," dalam kabar24.bisnis.com.

\section{Informan:}

\footnotetext{
Abdurrahman Mawazi, pengamat sosial keagamaan sekaligus dosen STAIN Sultan Abdurrahman, Kepulauan Riau, 24 November 18.

Riau Ust. Syarifuddin, S.Pd.I, Ketua Bidgar Dakwah Pimpinan Wilayah Persis, pada 19 September 2018.

Ust. Yana Mulyana, S.Pd.I, Ketua Pimpinan Wilayah Persatuan Islam Riau, pada 22 September 2018.

Ust. Zaki, Pengurus Persis Wilayah Pekanbaru, pada 18 September 2018.
}

Ustadzah Okti, Ketua Pesistri, pada 18 September 2018.

Ust. Mukhtar, Pengurus Cabang Persis Kuansing, pada 19 September 2018.

Anggota/jama'ah Persis Riau, pada 19 September 2018.

Ketua HIMA Persis Riau, 23 September 2018.

Lukman, pelaku bisnis dan UMKM di Batam, 25 November 18. 